\title{
Evaluating the Impact of the Registered Provisional Immigrant Program: A Cost-Benefit Analysis
}

\author{
by Odia Bintou Cissé
}

$\mathrm{O}$ n June 27, 2013, the Senate passed the Border Security,

Economic Opportunity, and Immigration Modernization Act of 2013 (referred to as S.744). The bill addresses key elements of the immigration process through five sections. This analysis serves as an ex-ante Cost-Benefit Analysis (CBA) of the proposed Registered Provisional Immigrant (RPI) program under Section II of S.744, which would allow undocumented immigrants in the US to obtain legal status. The CBA looks at a 10-year timeframe from 2015 through 2025 and estimates the costs and benefits to four groups: undocumented immigrants, US taxpayers, employers of undocumented immigrants, and the United States Citizenship and Immigration Services (USCIS) under a base case scenario, a distributional weight scenario, and a worst-case scenario. Given the positive net benefits observed under the three scenarios, significant evidence recommends the implementation of the RPI program. 


\section{INTRODUCTION}

On April 16, 2013, a bipartisan group of eight Senators introduced the Border Security, Economic Opportunity, and Immigration Modernization Act of 2013 (S.744). This proposal, which passed the Senate on June 27, 2013 but never passed the House of Representatives, addressed key elements of the immigration process. The bill aimed to control legal immigration, protect the borders, and maintain the sovereignty of the country (S.744 2013). The bill proposed clear rules for granting Lawful Permanent Residence status to existing undocumented immigrants (Immigration Policy Center 2013). The bill proposed a revision of laws regulating immigration and their enforcement. S.744 contained five sections addressing key aspects of the immigration process.

This paper serves as an ex-ante CostBenefit Analysis (CBA) of the proposed Registered Provisional Immigrant (RPI) program under Section II of S.744, which would allow undocumented immigrants in the US to obtain legal status. The analysis attempts to quantify the costs and benefits of the proposed RPI program, to assess the overall impact of the program, and to provide policy recommendations. Previous studies have looked at the overall impact of the bill, but this analysis focuses solely on the RPI program. This paper first provides an overview of the RPI program and establishes the perspective and standing in the CBA. The paper moves on to describe the assumptions and calculations underlying the analysis. The paper then provides a sensitivity analysis and concludes with recommendations.

\section{OVERVIEW OF THE RPI PROGRAM}

The RPI program would grant eligible undocumented immigrants legal status for an initial six-year period and would be renewable for those continuing to meet the eligibility requirements. RPIs would be eligible to apply for "Lawful Permanent Resident” (LPR) status following a 10year period under RPI status. RPIs would then be able to apply for US citizenship after maintaining LPR status for three years (Immigration Policy Center 2013). Therefore, RPIs would have to wait at least 13 years before becoming US citizens.

The RPI program is not to be confused with the LPR program. An LPR is "any person not a citizen of the United States who is residing in the US under legally recognized and lawfully recorded permanent residence as an immigrant" (USCIS 2013). LPRs are eligible for federal means-tested welfare benefits such as the premium tax credit and Affordable Care Act subsidies. After a five-year waiting period, LPRs are also eligible for Supplemental Nutrition Assistance (SNAP or "food stamps"), Medicaid, Children's Health Insurance Program, Temporary Assistance for Needy Families, and Social Security's Supplemental Security Income Program (NACO 2013).

An RPI would be considered an individual who is not a US citizen or US national but lawfully lives in the United States. The status of an RPI would be similar to the status of temporary (nonimmigrant) workers, granting the individual the right to work legally in the United States for a fixed period of time and making the individual liable for taxes on any income subject to tax. The main differences between the RPI and temporary work visas are: 
1. Unlike RPIs, temporary visas require the prospective employer to sponsor the employee, filing a petition with the USCIS.

2. Temporary visas require specialized skills or education, while there are no specific skills or education requirements for RPI applicants.

3. The RPI program, unlike temporary work visas, offers a path to citizenship (DOS 2015).

The RPI program also has provisions for undocumented immigrants who entered the US as children (under the age of 16) under its proposed DREAM Act. Beneficiaries of the DREAM Act, referred to as DREAMers, would apply for RPI status as other undocumented immigrants, but would not be subject to the $\$ 1,000$ penalty fee (CBO 2013). This analysis assumes DREAMers would have the same treatment as other RPIs in terms of adjusting to LPR status and US citizenship. The RPI provides an opportunity for undocumented immigrants who meet the following RPI requirements to obtain legal status.

\section{Physical presence}

An undocumented immigrant wishing to obtain RPI status must have been in the United States on or before December 31,2011 , and must remain present in the country until granted RPI status. Spouses and children of RPIs would also be eligible for RPI status only if they were present in the United States on or before December 31, 2012 and remain in the country until their RPI status is granted (S.744 2013).

\section{Criminal record}

To be eligible for RPI status, the individual must not have been convicted of a felony, an aggravated felony, three or more misdemeanors, or other offenses such as unlawful voting. RPI status is also contingent upon successful completion of background checks, and individuals who have participated in terrorist acts or have committed other criminal offenses would not be eligible for RPI status (S.744 2013).

\section{Payment of taxes}

Eligibility to the RPI status is also contingent upon payment of all federal tax liabilities (Schey 2015).

\section{Fees and penalty}

Undocumented immigrants wishing to obtain RPI status must pay a $\$ 1,000$ penalty along with the necessary application fees. DREAMers, however, are exempt from the $\$ 1,000$ penalty but have to pay processing fees associated with their applications (CBO 2013; S.744 2013). Adult RPIs may pay the $\$ 1,000$ through installments (Immigration Policy Center 2013). To renew RPI status, an individual must have paid the full amount of the initial $\$ 1,000$ penalty. The author assumes there are no additional penalty fees upon renewal of the RPI status because no additional penalty is explicitly stated in the bill. However, the applicant will still need to cover the costs of the application and other associated fees to renew RPI status.

After six years, RPIs can renew their status and later begin the process for LPR status (S.744 2013). RPIs can change to LPR status at the end of a continuous 10year period as an RPI (Immigration Policy Center 2013). To renew or adjust, RPIs need to meet the additional criteria below: 


\section{Average income}

Undocumented immigrants who wish to renew their RPI status following the initial six-year period must show regular employment during that period or "average income or resources not less than 100 percent of the Federal Poverty Level (FPL) throughout the period of admission as a RPI” (Schey 2013). To be eligible for LPR status, the immigrant must provide proof that during his/her period as a RPI, his/her average income or resources were above 125 percent of the FPL (S.744 2013).

\section{Continuous employment}

To renew or change their status, RPIs must show regular employment over the initial six-year period. This criterion allows for brief periods of unemployment not exceeding 60 days (S.744 2013).

\section{PERSPECTIVE AND STANDING IN THE CBA}

The geographic scope of this CBA analysis is the national perspective (United States). This analysis takes a federal perspective and gives all US taxpayers standing in this case. Undocumented immigrants would be significantly affected by the policy and are thus also given standing. This analysis looks at a 10-year timeframe beginning in 2015 and estimates the costs and benefits to four groups: undocumented immigrants, US taxpayers, employers of undocumented immigrants, and the United States Citizenship and Immigration Services (USCIS).

Previous studies have estimated the overall impact of S.744; the Heritage Foundation and the Congressional Budget Office ( $\mathrm{CBO}$ ) have estimated the impact of the bill for 50 years and 20 years respectively. The Center for American Progress (CAP) has also estimated the impact of granting legal status and citizenship to undocumented immigrants under three case scenarios, but only takes into account the increase in GDP and income fostered by the initiative. The analysis presented here, however, focuses solely on the proposed RPI program.

\section{ASSUMPTIONS AND CALCULATIONS: Number of applicants:}

The number of undocumented immigrants who would choose to apply to the program and the number who would be deemed eligible for the program is a significant determinant of the costs and benefits associated with the RPI program. The Pew Research Center estimates 11.3 million undocumented immigrants live in the United States as of 2013 (Passel et al. 2014). A 2013 report from the Heritage Foundation suggests that 99 percent of those undocumented immigrants were in the United States prior to December 31, 2011 (Rector and Richwine 2013). According to the Pew Research Center, the estimated undocumented immigrant population has remained almost the same since 2009, with little to no growth (Passel et al. 2014). Pew also estimates undocumented immigrant adults have been in the United States for a median of 13 years (Passel et al. 2014).

The base case scenario assumes current immigration trends will continue, and the introduction of the RPI program will not impact future flows of undocumented immigrants. This assumption is based on the idea that future undocumented immigrants would not benefit from the 
RPI program because only those who have been living in the United States since before December 31, 2011 would be eligible. Moreover, a study conducted to estimate the effect of the Immigration Reform and Control Act (IRCA) of 1986 suggested there was no evidence IRCA altered undocumented migration flows from Mexico (Donato, Durand, and Massey 2013). A Cato Institute study of IRCA's impact suggests the amnesty program did not alter the patterns of undocumented immigration from Mexico in the long run (Orrenius and Zavodny 2012). This assumption is also based on the fact that RPIs would not be eligible for federal means-tested benefits and therefore the RPI program does not provide an incentive to move to the United States. Furthermore, spouses and children of RPIs would be eligible for RPI status only if they had been physically living in the United States on or before December 31, 2012. Therefore, this paper assumes there will be no increase in the number of undocumented immigrants wishing to reunite with their RPI spouses or parents as a result of the program.

It is worth mentioning that this analysis predicts a potential increase in the US population 10 years following the enactment of the bill, when the first wave of RPIs would be granted LPR status, thereby earning the right to petition for visas for their spouses and children (Enchautegui, Linder, and Poethig 2013). However, because this study only looks at a 10-year timeframe, it does not reflect the increase in the US population from 2024 and beyond. Further analyses with a longer timeframe are needed to address the aforementioned change.

This analysis assumes about 10 percent of the 11.3 million undocumented immigrants living in the United States would qualify to benefit from the DREAM Act. This percentage is consistent with a study conducted by the Migration Policy Institute (MPI) in 2011, which analyzed data from the 2011 American Community Survey (ACS) and the 2008 Survey of Income and Program Participation (SIPP) to build a demographic and socioeconomic profile of undocumented immigrants. The MPI study estimated that as of 2011, 10 percent of the total undocumented immigrant population was under the age of 18, an estimate of 1.15 million people (Capps et al. 2013). CBO's 2013 cost estimate of S.744 is consistent with the MPI study, estimating that 1.5 million undocumented immigrants would obtain legal status as DREAMers (those who entered the United States under the age of 16) (CBO 2013). This analysis assumes about 1.2 million (approximately 10 percent) undocumented immigrants would obtain RPI status through the DREAM Act, assuming a slight increase from the 2011 and 2008 data.

In addition to those receiving RPI status through the DREAM Act, this analysis assumes a significant portion of the remaining nine million undocumented immigrants would not meet the requirements or would not apply (Schey 2013), potentially due to factors such as the high costs associated with the RPI application and limited access to information. This analysis therefore assumes that five million undocumented immigrants would be eligible for and would receive RPI status. This estimate is consistent with literature available on the number of undocumented immigrants who would be granted RPI status. For example, $\mathrm{CBO}$ estimated that 6.8 million 
people would register for RPI status. Of the 6.8 million registered, 1.5 million would obtain RPI status as DREAMers. CBO also estimated that a small percentage of those who initially register would not meet the requirements set forth in the bill (CBO 2013). Additionally, the Center for Human Rights and Constitutional Law, in an analysis of the S.744, estimates that 4 to 5 million undocumented immigrants would meet the requirements and be granted RPI status (Schey 2013).

This analysis assumes the program would be implemented at the end of 2014, with the first wave of applicants applying for and being granted RPI status at the beginning of 2015. The paper therefore assumes no delay between enactment and implementation of the program.

Undocumented immigrants who wish to obtain RPI status would have a period of 12 months to submit their applications (S.744 2013). The US Congress reserves the right to extend the period, should they determine that an extension is necessary (S.744 2013). This analysis assumes all applications would be submitted and processed in 2015.

\section{CALCULATION OF BENEFITS AND COSTS}

The table below provides an overview of the benefits and costs associated with each group.

By giving qualified undocumented immigrants legal status, the proposed RPI program would benefit the undocumented immigrant population and the overall US economy. The benefits include an increase in wages for the RPI, an increase in federal payroll and income taxes collected from RPIs, and revenues from the RPI penalty fees and other application fees.

\section{METHODOLOGY}

This section presents the methodology used to calculate the benefits. Other studies of the impact of a legalization of undocumented immigrants have included the change in Gross Domestic Product (GDP) in their estimate of the benefits (CBO 2013); however, this analysis does not take into account the change in GDP, as the author believes such change is reflected in the estimated increase in wages and taxes collected.

\section{Increase in wages}

Granting legal status to undocumented immigrants is associated with an increase in their productivity, which Orrenius and Zavodney say can be explained by improved English language skills resulting from obtaining legal status (2012). Orrenius and Zavodney argue that improved English skills lead to improved labor skills. Lynch and Oakford (2013) suggest that granting legal status to undocumented immigrants is associated with an increase in their average wages. These studies assert that legal status allows formerly undocumented immigrants to apply for better jobs and increases their bargaining power in wage discussions with employers. Under current laws, undocumented immigrants are not permitted to work in the United States. Therefore, employers are reluctant to hire undocumented immigrants or will only hire them at very low wages (Lynch and Oakford 2013).

Additionally, granting legal status to undocumented immigrants could foster entrepreneurship by giving them access to credit, insurance, and the permits they would need to start businesses (Lynch and Oakford 2013). An Urban Institute assessment of various studies on the impact of the 1986 IRCA found that 


\begin{tabular}{|c|c|c|}
\hline Group & Benefits & Costs \\
\hline $\begin{array}{l}\text { Undocumented } \\
\text { Immigrants who } \\
\text { would obtain RPI } \\
\text { Status }\end{array}$ & $\begin{array}{l}\text { - Higher wages (quantified } \\
\text { at over } \$ 974 \text { million in } \\
2015 \text { under the base case } \\
\text { scenario). } \\
\text { - Ability to travel inside } \\
\text { and outside of the US } \\
\text { (not quantified). } \\
\text { - Peace of mind (not quan- } \\
\text { tified). }\end{array}$ & $\begin{array}{l}\text { - Application fees (quantified at } \\
\text { over } \$ 6 \text { billion in } 2015 \text { under the } \\
\text { base case scenario). } \\
\text { - Penalty fees (quantified at } \$ 5 \text { bil- } \\
\text { lion in } 2015 \text { under the base case } \\
\text { - scenario). } \\
\text { - Time spent on applications } \\
\text { (quantified at over } \$ 5 \text { billion in } \\
\text { 2015 under the base case scenar- } \\
\text { io). } \\
\text { - Payroll taxes (quantified together } \\
\text { with the cost to employers). } \\
\text { - Risk of deportation (not quanti- } \\
\text { fied). }\end{array}$ \\
\hline US taxpayers & $\begin{array}{l}\text { - Increase of federal pay- } \\
\text { roll and income taxes } \\
\text { (quantified at } \$ 6.9 \text { billion } \\
\text { in } 2015 \text { under the base } \\
\text { case scenario). } \\
\text { - Change in social surplus } \\
\text { from the increase in the } \\
\text { USCIS workforce (quan- } \\
\text { tified at over } \$ 1 \text { billion in } \\
2015 \text { under the base case } \\
\text { scenario). }\end{array}$ & \\
\hline
\end{tabular}

$\begin{array}{lll}\begin{array}{l}\text { Employers of } \\ \text { undocumented }\end{array} & \begin{array}{l}\text { Peace of mind for those } \\ \text { who have hired undocu- } \\ \text { immigrants }\end{array} & \begin{array}{l}\text { - Higher wages (quantified at } \\ \text { approximately } \$ 5 \text { billion in } 2015 \\ \text { quantified). }\end{array}\end{array}$

- Revenues from penalty fees (quantified at $\$ 5$ billion in 2015 under the base case scenario).

USCIS

- Revenues from application fees (quantified at

- Costs of expanding the workforce (quantified at $\$ 5$ billion in 2015 over $\$ 6$ billion in 2015 under the base case scenario). 
undocumented immigrants who obtain legal status have an estimated increase in wages of four to 10 percent (Enchautegui, Linder, and Poethig 2013). CAP estimates that granting legal status to the current undocumented immigrant population would lead to a 15 percent increase in wages of the legalized within five years, as a result of increased productivity (Lynch and Oakford 2013). The author considers CAP's estimated increase in wages too optimistic because it assumes the increase in wages is only related to changes in productivity. CAP fails to take into account that wages represent transfers from employers (Lynch and Oakford 2013). The CBO estimates a 12 percent increase in wages of the RPIs in 10 years (2013). Under the base case scenario, this analysis uses a 10 percent cumulative increase in wages through 2024.

The Pew Research Center estimated that in 2007, median household income of undocumented immigrants was $\$ 36,000$ and the average family size was 2.29 (Passel and Cohn 2009; Passel and Cohn 2011). Analyzing the 2009-2011 ACS, the Institute on Taxation and Economic Policy (ITEP) estimated the annual income of undocumented families at $\$ 33,100$ (2013). Dividing the average household income estimated by the Pew Research Center by the average size of the undocumented household $(\$ 36,000 / 2.29)$ gives an estimated $\$ 15,720$ average income for an undocumented immigrant.

To calculate the impact of the RPI program on undocumented immigrants' wages, this analysis multiplies the estimated number of RPIs by the average income of undocumented immigrants $(\$ 15,720)$; then multiplies the total by an incremental one percent increase per year (for a cumulative 10 percent increase by year 2024).

\section{Increase in federal tax revenues/ Fiscal impact}

Few studies have attempted to estimate the impact of legalization of undocumented immigrants on federal tax revenues. However, studies that estimated the total impact of S.744, discussed above, included estimates of the federal tax impact. CAP estimated that granting legal status to undocumented immigrants would lead to an increase of $\$ 69$ billion in federal taxes over 10 years (Lynch and Oakford 2013), the equivalent of a change of $\$ 6.9$ billion per year assuming a constant and stable change over the 10 -year period. In a comparative study of the economic and fiscal impacts of immigration reform, researchers with the Urban Institute used the CBO's cost estimate of S.744 to calculate the fiscal impact of granting legal status as $\$ 2,251$ per new legal immigrant per year from 2014 through 2023 (Enchautegui, Lindner, and Poethig 2013). Multiplying $\$ 2,251$ by the number of legal immigrants per year (DREAMers and RPIs) leads to an increase of approximately $\$ 14$ billion. In the base case scenario, this analysis uses the CAP estimate of granting legal status, and assumes an increase of $\$ 6.9$ billion per year in federal revenue as a result of the program.

The fiscal impact of legalizing undocumented immigrants is in part explained by changes in payroll and income taxes. Studies estimate that income and payroll taxes are already withheld for more than half of the undocumented immigrant population (Orrenius and Zavodny 2012). The author assumes that as undocumented immigrants obtain legal status, payroll and income taxes would be collected for those who used to work in the black market and were not subjected to income and payroll taxes. Additionally, 
as a result of higher incomes, US taxpayers would collect additional federal payroll and income taxes. The additional federal payroll and income taxes result from the Federal Individual Income Tax Rates, a progressive tax model.

\section{Revenues from penalty fees}

The Department of Homeland Security (DHS), through the USCIS, would collect a penalty fee from each applicant seeking to obtain RPI status (S.744 2013). The penalty fees would result in a transfer from undocumented immigrants to the American taxpayer. This CBA estimates this revenue by multiplying the $\$ 1,000$ penalty fee by the number of applicants eligible for RPI status, not including DREAMers. Although an installment plan would be available and would offer the possibility to pay over the initial sixyear period, it is impossible to predict the percentage of applicant who would use the installment plan. For ease of calculation, this analysis assumes all applicants pay their penalty as a lump sum at the time of application in the beginning of 2015 . The total revenues from penalty fees are calculated by multiplying the number of eligible applicants $(5,000,000)$ by $\$ 1,000$ in 2015. Revenues from penalty fees are therefore estimated at $\$ 5$ billion.

\section{Revenues from application fees}

The DHS, through the USCIS, would collect application fees to cover the cost of processing applications and other related fees. Currently, fees total $\$ 1,070$, including a form fee of $\$ 985$ to people age 14-78 and an $\$ 85$ biometric services fee (USCIS 2015). DREAMers are also required to pay the application and other related fees, and the fees need to be paid again when renewing RPI status (S.744 2013). This analysis assumes those fees are paid in full in 2015 and 2021 (at the time of RPI status renewal). To calculate the net revenues from application fees, this analysis multiplies the total number of eligible applicants by $\$ 1,070$.

\section{Change in Social Surplus from the increase USCIS workforce}

Should the RPI program be enacted, the USCIS would need to increase its workforce capacity to handle the large number of applications. The increase in the USCIS workforce is associated with change in social surplus. According to the Bureau of Labor Statistics, the unemployment rate in the United States as of November 2014 was 5.8 percent (DOL 2014). At that rate, the US labor market is neither considered an efficient nor an inefficient labor market. To estimate the change in social surplus as a result of the increased USCIS workforce, this analysis estimates that only a quarter of wages earned would be considered a change in social surplus. Using only a quarter as a ratio to estimate the change in social surplus is in line with the principles of a CBA. The total wages received by USCIS workers as a result of the introduction of the RPI program represents a cost to US taxpayers. This analysis explains the calculation of the total costs in the next section.

\section{CALCULATION OF COSTS Costs to Undocumented Immigrants 1. Cost of penalty fee}

To earn RPI status, eligible undocumented immigrants must pay a one-time $\$ 1,000$ penalty fee per person. Those who qualify as DREAMers are not required to pay 
the penalty fee. To calculate the cost of application fees, the number of RPIs (excluding DREAMers) is multiplied by $\$ 1,000$. The cost associated with the penalty fee is a transfer from undocumented immigrants to the US taxpayers.

\section{Cost of application}

Undocumented immigrants must pay application and other related fees to obtain, and six years later to renew, RPI status. The application fees for RPI status have not been set. This analysis uses the current fees charged for an application for LPR status to estimate the cost of all related fees. As mentioned above, USCIS charges a $\$ 1,070$ application fee for the LPR application, which DREAMers are also required to pay (USCIS 2015). The fees need to be paid again to renew RPI status. To calculate the costs of the application and other related fees, the author multiplies $\$ 1,070$ by the total number of RPIs and DREAMers who would apply for legal status in 2015. RPIs would also be required to pay the application fees upon renewal following the six-year initial period. However, due to the requirements associated with renewing RPI status, especially the employment requirement discussed earlier in the paper, this analysis assumes that not all who are granted initial RPI status will renew their status. In their analysis of the undocumented immigrant population, MPI estimated that approximately 32 percent of undocumented immigrant adults (age 19 and over) have an income lower than 100 percent of the FPL (Capps et al. 2013). Because this analysis assumes an increase in wages and employment for RPIs, the base case scenario assumes that following the initial six-year RPI period, about 15 percent of RPIs would still have an income lower than the Federal Poverty Level, rendering them ineligible for RPI status renewal. This analysis assumes about 80 percent of RPIs, four million people, would complete the renewal process. Twenty percent of RPIs would be deemed ineligible because of failure to meet employment, resources, or criminal record criteria.

\section{Time spent on application}

Undocumented applicants wishing to obtain RPI status must dedicate a considerable amount of time on the application, making trips to the USCIS bureaus, collecting information on the process, seeking advice, gathering information to establish their eligibility, and subjecting themselves to biometric services and other background checks. As mentioned earlier in this paper, the average income of an undocumented immigrant is estimated at $\$ 15,720$, which corresponds to an hourly wage of $\$ 7.56$. To quantify the cost of time spent by undocumented immigrants on their initial application, the estimated hourly wage of undocumented immigrants (\$7.56) is multiplied by an assumption of 100 hours and by the number of applicants in the base case scenario. The estimate of hours dedicated to renewing their RPI status would be about 20 percent of the time dedicated to the initial application and would take into account a 6 percent increase in the hourly wage of undocumented immigrants, consistent with the annual increase in wages expected. This analysis assumes RPIs would be more familiar with the process and would therefore spend less time on the process. This analysis subjects this estimate of the amount of time needed to complete the application to sensitivity analysis. 


\section{Cost to Taxpayers}

\section{USCIS workforce}

Should the RPI program be enacted, the USCIS would need to increase its workforce capacity to handle the flow of millions of undocumented immigrants expected to seek legal status. USCIS employees are federal employees, and their wages are billed to the US taxpayers. To estimate the cost associated with the increase in the USCIS workforce, this analysis uses the average self-reported wages from USCIS workers on the Glassdoor website. The $\$ 70,000$ average income (corresponding to a $\$ 33.65$ hourly wage) reported on Glassdoor's website may not be a perfect metric to calculate the average wage of a USCIS Immigration Services Officer because it is self-reported and is based on a limited number of employees (Glassdoor 2015). A metasearch of average salaries of USCIS job postings on Indeed.com across the country provides salaries varying in the range of $\$ 50,000$ to $\$ 90,000$ and an average of $\$ 70,000$ for a USCIS Adjudications Officer. Due to of a lack of information on the number of hours it takes USCIS to process an application, the base case scenario assumes USCIS employees spend an average 24 hours of work per application. Therefore, the cost to US taxpayers due to changes in the USCIS workforce is calculated by multiplying the average hourly wages of the workers (\$33.65) with the number of hours (24) and the number of applicants (6.2 million) for a total of $\$ 5$ billion.

\section{Cost to Employers}

\section{Higher wages}

One of the benefits of legalizing undocumented immigrants is the increase in wages they receive. The change in the income of RPIs would stem from increased productivity, an increase in bargaining power with employers, and compliance with minimum-wage laws (Lynch and Oakford 2013). This analysis assumes approximately half of wage increases would transfers from employers to employees. Therefore, to calculate the cost to employers of higher wages, this analysis divides the total increase in RPIs' wages by two. In other words, 50 percent of the changes in revenues would be considered a transfer from employers to employees under this analysis. Studies of the IRCA Amnesty estimated the changes in productivity associated with legalizing undocumented immigrants correlated with a four to six percent increase in wages over a 10-year period (Kossoudji and CobbClark 2002; Barcellos 2010). Therefore, this analysis assumes five percent of the 10 percent increase in wages is the result of a transfer from employers to employees and the remaining five percent increase is associated with changes in productivity.

\section{Cost of payroll and income taxes to RPIs and employers}

An important portion of the fiscal impact of the legalization of undocumented immigrants is a transfer from employers and RPI to the US taxpayers through payroll and income taxes. This analysis assumes in the base case scenario that 40 percent of the change in federal revenue is a transfer from RPIs and employers to the US taxpayers. In the base case scenario, the cost of payroll and income taxes to RPIs and employers is calculated by multiplying the overall fiscal impact of legalizing undocumented immigrants by 40 percent. 


\section{NET BENEFITS}

Table 1, below, presents the total costs and benefits of the RPI program from 2015 through 2024. To calculate the Net Present Value (NPV) of future costs and benefits of the RPI program, this analysis uses a standard 3 percent discount rate to reflect the long-range aspect of the program. The NPV of total costs is subtracted from the NPV of total benefits.

\section{OTHER CONSIDERATIONS}

This CBA excludes the non-quantifiable costs and benefits that should be taken into account in weighting the benefits and costs of the proposed program. For instance, obtaining legal status would allow formerly undocumented immigrants to freely travel to their home countries and visit their families. Currently, undocumented immigrants wishing to visit home or travel within the United States run the risk of facing deportation if discovered without travel documents. Granting legal status would provide peace of mind to undocumented immigrants who live with the constant fear of deportation. These benefits and costs are not quantifiable but are worth mentioning.

Another effect that this analysis does not account for is the effect of granting LPR or citizenship status in the future to current undocumented immigrants. Should the US Government give RPIs the opportunity to apply for LPR or citizen status within 10 years, RPIs would gain access to federal means-tested benefits, generating significant costs to US taxpayers.

\section{ANALYSIS}

Table 1 above provides calculations of the different costs and benefits associated with the RPI program. Under the base case scenario, this analysis estimates the NPV of benefits from the program would be $\$ 84$ billion while the NPV of costs associated with the program would be approximately $\$ 55$ billion, resulting in net benefits of

Table 1: Summary of NPV Calculations

\begin{tabular}{|cccc|} 
& Base Case Scenario & $\begin{array}{c}\text { Distributional } \\
\text { Weight Scenario }\end{array}$ & Worst-case Scenario \\
\hline $\begin{array}{c}\text { Net Present } \\
\text { Value of } \\
\text { Benefits }\end{array}$ & $\$ 84,012,703,094.75$ & $\$ 91,527,051,973.68$ & $\$ 39,513,725,830.34$ \\
$\begin{array}{c}\text { Net Present } \\
\text { Value of Costs }\end{array}$ & $(\$ 55,391,036,529.67)$ & $(\$ 72,341,961,119.05)$ & $(\$ 37,065,441,202.38)$ \\
$\begin{array}{c}\text { Net Benefits }(= \\
\text { NPV of Benefits } \\
- \text { NPV of Costs })\end{array}$ & $\$ 28,621,666,565.08$ & $\$ 19,185,090,854.63$ & $\$ 2,448,284,627.95$ \\
\hline
\end{tabular}


approximately $\$ 29$ billion. RPIs bear most of the costs. US taxpayers benefit the most from the RPI program. This analysis relies heavily on assumptions and estimates. Therefore, this analysis does not perfectly predict the net benefits of the program, but suggests that granting legal status to undocumented immigrants would bring large positive economic benefits.

\section{SENSITIVITY ANALYSIS}

\section{A. Distributional weight}

Undocumented immigrants seeking to obtain legal status bear most of the costs. Since the undocumented immigrant population is a low-income population, one might wish to account for the distributional issues of this study. If policy makers are interested in enhancing equity and improving the lives of undocumented immigrants, the findings should assign distributional weights to reflect the value placed on each dollar paid or received by the undocumented immigrant population. This section explores the effect of assigning a distributional weight to the findings presented in the analysis.

In this sensitivity analysis, a standard differential weight of two is assigned to the costs and benefits of undocumented immigrants. The distributional weight affects the base case scenario as follows:

Assigning a distributional weight does not alter the findings of the analysis. Although the net benefits decrease by $\$ 9.5$ billion, the RPI program is still found to have significant positive impact of $\$ 19$ billion. The decrease in net benefits is linked to a 30 percent increase in the net present value of costs against an 8 percent increase in the NPV of benefits. The second column of table 1 shows the calculations associated with assigning the distributional weight. The similar findings between the base case scenario and the sensitivity analysis using a distributional weight might be explained by the fact that changes in the amount of federal taxes collected, which represents the greater share of benefits of the program, are unaffected by the distributional effect.

\section{B. Worst-case scenario}

This analysis assumes that legalizing undocumented immigrants would lead to an increase in their wages and federal taxes collected. One might contest this premise. Therefore, this section tests whether the findings would be consistent under a worst-case scenario as follows:

- An increase of RPI wages of 4 percent over 10 years; instead of the 10 percent increase assumed under the base case scenario; and

- An increase in the federal tax revenue of $\$ 23$ billion over 10 years compared to the base case estimate of $\$ 69$ billion.

Under the worst-case scenario (See Table 1), the net benefits of the program significantly decrease but remain positive at over $\$ 2$ billion.

\section{POLICY RECOMMENDATION}

Given the positive net benefits observed under a variety of scenarios, there is significant evidence to recommend the implementation of the RPI program, granting legal status to millions of undocumented immigrants currently living in the United States. Although the bill never passed the House, the immigration question and the status of thousands of 
undocumented immigrants will be central to the next presidential election and needs to be addressed. Whether S.744 should be enacted is beyond the scope of this paper; however, based on the findings presented above, the RPI program should be given a second chance.

\section{REFERENCES}

Barcellos, Silvia Helena. 2010. "Legalization and the Economic Status of Immigrants." Working Paper WR-754. Santa Monica, CA: RAND Corporation. http://www. rand.org/content/dam/rand/pubs/working_papers/2010/RAND_WR754.pdf.

Border Security, Economic Opportunity, and Immigration Modernization Act. S.744. 113th Cong. (2013). https://www.congress.gov/bill/113th-congress/senatebill/744/text.

Capps, Randy, Michael Fix, Jennifer Van Hook, and James D. Bachmeier. 2013. "A Demographic, Socioeconomic, and Health Coverage Profile of Unauthorized Immigrants in the United States." Washington, D.C.: Migration Policy Institute. Accessed January 16, 2016. http://www.migrationpolicy.org/research/ demographic-socioeconomic-and-health-coverage-profile-unauthorizedimmigrants-united-states.

Congressional Budget Office (CBO). 2013. "The Economic Impact of S.744, the Border Security, Economic Opportunity, and Immigration Modernization Act.” Accessed January 15, 2016. https://www.cbo.gov/sites/default/files/113thcongress-2013-2014/reports/44346-Immigration.pdf.

Donato, Katharine M., Jorge Durand, and Douglas S. Massey. 1992. "Stemming the Tide? Assessing the Deterrent Effects of the Immigration Reform and Control Act". Demography 29 (2). Springer: 139-57. http://www.jstor.org/ stable/2061724.

Enchautegui, Maria E., Stephen Lindner, and Erika Poethig. 2013. "Understand the Economic and Fiscal Impacts of Immigration Reform." Washington, D.C.: The Urban Institute. Accessed January 16, 2016. http://www.urban.org/research/ publication/understanding-economic-and-fiscal-impacts-immigration-reform/ view/full_report.

Glassdoor. 2015. "US Citizenship and Immigration Services Salaries." Last modified January 24. http://www.glassdoor.com/Salary/US-Citizenship-andImmigration-Services-Salaries-E41353.htm. 
Immigration Policy Center. 2013. "A Guide to S.744: Understanding the 2013 Senate Immigration Bill." Accessed January 15, 2016. http://www.immigrationpolicy. org/special-reports/guide-s744-understanding-2013-senate-immigration-bill.

Institute on Taxation and Economic Policy. 2013. "Undocumented Immigrants' State and Local Tax Contributions.” Accessed January 15, 2016. http://www.itep.org/ pdf/undocumentedtaxes.pdf.

Internal Revenue Service (IRS). 2015. “Taxation of Nonresident Aliens.” Last modified November 10, 2015. https://www.irs.gov/Individuals/International-Taxpayers/ Taxation-of-Nonresident-Aliens.

Kossoudji, Sherrie A. and Deborah A. Cobb-Clark, 2002."Coming out of the Shadows: Learning about Legal Status and Wages from the Legalized Population." Journal of Labor Economics 20(3): 598-628. Accessed January 15, 2016. https://ideas. repec.org/a/ucp/jlabec/v20y2002i3p598-628.html.

Lynch, Robert and Patrick Oakford. 2013. “The Economic Effects of Granting Legal Status and Citizenship to Undocumented Immigrants.” Washington, D.C.: Center for American Progress. Accessed January 16, 2016. https://cdn.americanprogress.org/wp-content/uploads/2013/03/ EconomicEffectsCitizenship-1.pdf.

National Association of Counties (NACO). 2013. "Comprehensive Immigration Reform and the Outlook for Counties.” Last modified June 1. http://www.naco.org/ legislation/Documents/NACo-Immigration-Presentation.pdf.

Orrenius, Pia and Madeline Zavodny. 2012. "The Economic Consequences of Amnesty of Unauthorized Immigrants." Cato Journal 32 (1): 85-106. http://object.cato. org/sites/cato.org/files/serials/files/cato-journal/2012/1/cj32n1-7.pdf.

Passel, Jeffrey and D’Vera Cohn. 2009. “A Portrait of Unauthorized Immigrants in the United States." Washington, D.C.: Pew Hispanic Center. Accessed January 15, 2016. http://www.pewhispanic.org/2009/04/14/a-portrait-ofunauthorized-immigrants-in-the-united-states/?utm_expid=53098246-2. Lly4CFSVQG2lphsg-KopIg.0.

.2011. "Unauthorized Immigrant Population: National and State Trends, 2010." Washington, D.C.: Pew Hispanic Center. Accessed January 15,.2016. http://www.pewhispanic.org/2011/02/01/unauthorized-immigrantpopulation-brnational-and-state-trends-2010/?utm_expid=53098246-2. Lly4CFSVQG2lphsg-KopIg.0. 
Passel, Jeffrey S., D’Vera Cohn, Jens Manuel Krogstad, and Ana Gonzalez-Barrera. 2014. "As Growth Stalls, Unauthorized Immigrant Population Becomes More Settled." Washington, D.C.: Pew Research Center's Hispanic Trends Project. Accessed January 15, 2016. http://www.pewhispanic.org/2014/09/03/as-growth-stallsunauthorized-immigrant-population-becomes-more-settled.

Rector, Robert and Jason Richwine. 2013. “The Fiscal Cost of Unlawful Immigrants and Amnesty to the US Taxpayer." Washington, D.C.: The Heritage Foundation. Accessed January 15, 2016. http://www.heritage.org/research/reports/2013/05/ the-fiscal-cost-of-unlawful-immigrants-and-amnesty-to-the-us-taxpayer.

Schey, Peter. 2013. "Analysis of Senate Bill 744's Pathway to Legalization and

Citizenship." Los Angeles: Center for Human Rights and Constitutional Law. Accessed January 15, 2016. http://www.nnirr.org/ nnirrorg/drupal/sites/ default/files/6-18-13_chrcl-peter_schey_analysis_senate_bill_legalization_ program.pdf.

US Citizenship and Immigration Services (USCIS). 2013. "Lawful Permanent Resident (LPR).” Accessed January 15, 2016. http://www.uscis.gov/tools/glossary/lawfulpermanent-resident-lpr.

2015. “I-485, Application to Register Permanent Residence or Adjust Status." Last updated November 6, 2015. http://www.uscis.gov/i-485.

US Department of Labor (DOL), Bureau of Labor Statistics. 2014. "Labor Force Statistics from the Current Population Survey." Accessed January 15, 2016. http://data.bls.gov/timeseries/LNS14000000.

US Department of State (DOS), Bureau of Consular Affairs. 2015. "Temporary Worker Visas." Accessed February 14, 2016. https://travel.state.gov/content/visas/en/ employment/temporary.html 


\section{ODIA BINTOU CISSÉ recently graduated from the Trachtenberg School} of Public Policy and Public Administration with her Master of Public Administration. Odia currently works at an international Non-Governmental Organization, where she provides support to the agriculture and food security portfolio. A travel enthusiast, Odia is originally from Côte d'Ivoire, is fluent in French, and has limited proficiency in Spanish. Odia is also an avid follower of "Humans of New York" and loves to explore DC's food scene. Odia holds a Bachelor of Business Administration in Finance and Economics.

In the past, Odia served as an Associate Editor and a Senior Associate Editor with Policy Perspectives, Volume 21 and 22 respectively.

\section{ACKNOWLEDGEMENTS}

The author thanks the editorial team, particularly Janette Martinez and Monika Jansen, and Dr. Dylan Conger for their feedback, patience, and support during the editing process. The author expresses her gratitude to Drs. William Adams and Donna Infeld for fostering her interest in research. Finally, the author is grateful for her phenomenal family and friends for their love and support. 